\section{Use of animals in research}

SIR-Professor Blakemore's attack (Nature 339, 414; 1989) on Clive Hollands for expressing his opinion on the publication of work on monkeys (Nature 339, 248; 1989 ) is hysterical and is also a thinlydisguised attack on the freedom of the individual.

Like Mr Hollands, I am a member of the Animal Procedures Committee (APC) created by the Animals (Scientific Procedures) Act 1986. We are more familiar than most with the content and intentions of the act, since we advised the British government at all stages of its preparation and passage through parliament. During this period we campaigned for an advisory committee free from the control of the Secretary of State, so we were delighted when David Mellor MP, then UnderSecretary of State at the Home Office, said in the House of Commons Committee on 13 March 1986 that the APC "will be able to tender advice to the Secretary of State whether or not he asks for it" (ATLA 14, 6-13; 1986). The rights of the APC and its members are defined by the law, not by the Home Secretary.

Membership of the APC does not preclude us from speaking out on any issue which concerns us, provided that we do not contravene the sections of the act which relate to the protection of confidential information. Mr Hollands does not mention his membership of the APC in his letter to Nature. I hope that Professor Blakemore, and any others who join him in writing to the Home Secretary, will receive the kind of reply I would expect if I asked the Chancellor of Oxford University to comment on the right of members of that important institution to pontificate in the way that we have come to expect of Professor Blakemore.

Like the vast majority of those in the animal welfare movement, $\mathrm{Mr}$ Hollands has repeatedly made clear his opinion that violence in the name of animal rights is illegal, unjustifiable and counterproductive. Terrorism in any form angers us no less than it angers Professor Blakemore.

Professor Blakemore says that "medical research is fighting for its survival" and that there are philistine forces which would "stop the progress of medicine". Most of medical research does not involve animal experimentation; much progress is being made, and would continue to be made, without it. This kind of emotional exaggeration damages the case which can be made for properly controlled experimentation on animals.

Professor Blakemore ends his letter with a snide remark about Mr Hollands and "his personal law". The 1986 act does not belong to Mr Hollands, and it certainly does not belong to Professor Blakemore. It belongs to all of us, and the legislatures of other countries, including France and the United States, would do well to examine it before undertaking much-needed reforms in their own legislation.

\section{FRAME,}

Michael Balls

Stoney Street, Nottingham NG1 1NB and University of Nottingham Medical School, Nottingham NG7 2UH, UK

SIR-Professor Blakemore's recent defence of Nature's publication of work involving two fetal macaque monkeys and their mothers (Nature 337, 265-267; 1989) offers little help in thinking about two serious ethical questions raised by $\mathrm{Mr}$ Hollands' criticisms.

The more general of these two questions concerns the publication in Britain of the results of animal research which would not have been allowed under British law. Should British journals publish such work? Blakemore, disappointingly, does not comment on this important issue, preferring instead to concentrate on the question of whether this particular piece of work would have been legal. The second question relates to whether the work was 'justified': were the 'benefits' accruing from the research sufficient to justify the 'cost' (in terms of pains and distress imposed on the animals used)? $\mathrm{Mr}$ Hollands clearly believes that the justification for the work was insufficient, or perhaps the work had not been sufficiently justified by the scientists, and so argues that the work would not have been permitted under British law. Professor Blakemore, on the other hand, suggests that the work was justified, but gives little evidence to support his view.

Professor Blakemore states that the work "addresses fundamentally important questions about the mechanisms of development of the cerebral cortex", but we are not informed how the results of this work advance understanding. Similarly, we are told that the work was "performed skilfully and humanely in one of the leading centres for biomedical research". All well and good, but what of the specific effects on the monkeys used in these particular experiments? The results represented are for only two animals - were others used? Only when such specific information is provided can other scientists (who are also part of the general public and like Professor Blakemore have been unwarranted targets of anti-vivisectionist abuse) be persuaded of the work's justification.

I hope that scientists will not in Professor Blakemore's words "mobilize to resist the philistine forces that would stop the progress of medicine", but, where possible, will attempt to meet temperate criticisms head on, by providing reasoned, detailed and logical answers to reasonable questions. Too often those with some ethical reservation about a piece of animal research are accused of being anti-science. That is simply not true. There are real and difficult practical ethical dilemmas involved in carrying out animal research and most scientists take these seriously. It is for that reason that rational debate on such issues is to be welcomed, and is partly the reason why one university has seen fit to create a department of Biomedical Science and (biomedical) Ethics to promote such discussions.

Unit of Biomedical Services,

DAVID B. MORTON

University of Leicester,

PO Box 138 ,

\section{Leicester LE1 9HN, UK}

While Nature's largest editorial office is in Britain, the legal basis of its publication is identical in Britain, Japan and the United States - Editor, Nature.

\section{Unfair anonymity}

SIR-Earlier this year a well known colleague received a rejection notice from a specialist journal whose decision was based on an excessively harsh, anonymous review. The colleague's response was extreme: suicide. Because he suffered from clinical depression, some other event might have eventually precipitated the same response. However, this tragedy highlights a widespread phenomenon. Most of us know individuals whose attitudes towards publication or pursuing a career in science have been marred by a hostile or ad hominem review. Most reviewers are fair-minded, but when scientists use an anonymous review as a means of denigrating their rivals, they undermine the spirit of science. Most authors take harsh reviews in their stride, but this means that the publication process favours authors with skin of a particular thickness.

This unwitting selection for scientific rhinoceroses comes at the expense of diversity. I am not advocating lower standards for acceptance of papers - but how many journals explicitly instruct their referees to focus their criticisms on the manuscript rather than its author? How many editors refuse reviews that are primarily personal attacks? How many reviewers look upon the review as a chance to have a positive influence on someone else's research?

Anonymous peer review has its advantages and disadvantages, but should surely be granted only to those willing to accept certain responsibilities.

CRAIG PACKER

Dept. of Ecology and Behavioral Biology,

University of Minnesota,

Minneapolis,

Minnesota 55455, USA 